Vol III. No.2, Maret 2019, hlm. 107 - 116

Available online at www.jurnal.una.ac.id/indeks/jmp

\title{
ANALISIS PROFIL GURU MATEMATIKA DALAM MEMBANGUN KONSEP DIRI SISWA
}

\author{
1) Yuliyanti,Widodo Winarso ${ }^{2)}$,Muhamad Ali Misri ${ }^{3)}$ \\ 1,2,3 IAIN Syekh Nurjati - Jl. Perjuangan By Pass Sunyaragi Cirebon 4513 \\ e-mail: ${ }^{1)}$ yuliyanticipwet@gmail.com,
}

\begin{abstract}
This study aims to analyze the profile of SMPN 1 Lemahabang mathematics teacher implicating or not in developing self-concept of students and how much influence the profile of SMPN 1 Lemahabang teacher in developing self-concept of students. This research is a quantitative study using the One ShotCase Study design, the sampling technique used was purposive sampling and a sample of 5 mathematics teachers and 178 students of Lemahabang Middle School was selected. The research method used is the teacher performance appraisal (PKG) and questionnaire/questionnaire. The results of this study indicate that: (1) the profile of mathematics teachers according to the results of teacher performance evaluations has an average value of $85.43 \%$ which falls into the good category. Strengthened by the mathematics teacher's profile according to student perceptions of an average score of $73.86 \%$ which is included in the medium category (2) students' self-concept has an average value of $65.23 \%$ which is included in the medium category (3) based on Data analysis shows that the mathematics teacher's profile has implications in building students' self-concepts. This can be seen from the price of $t$ count $=-0.836$ with a significance value of $-0.836<0.05$, so Ho is rejected and $\mathrm{Ha}$ is accepted, which means that there are implications for the teacher's profile in developing students' self-concept.
\end{abstract}

Keywords: MathematicsTeacherProfile, Teacher Performance, Self-Concept

\begin{abstract}
Abstrak
Penelitian ini bertujuan untuk menganalisis profil guru matematika SMPN 1 Lemahabang berimplikasi atau tidak dalam membangun konsep diri siswa dan seberapa besar pengaruh profil guru matematika SMPN 1 Lemahabnag dalam membangun konsep diri siswa. Penelitian ini merupakan penelitian kuantitatif menggunakan desain One ShotCase Study, teknik pengambilan sampel menggunakan purposive sampling dipilih sampel 5 orang guru matematika dan 178 siswa SMPN 1 Lemahabang. Metode penelitian yang digunakan adalah lembar hasil penilaian kinerja guru (PKG) dan angket/kuesioner. Hasil dari penelitian ini menunjukkan bawa: (1) profil guru matematika menurut hasil penilaian kinerja guru memiliki nilai rata-rata sebesar $85,43 \%$ yang termasuk ke dalam kategori baik. Diperkuat dengan profil guru matematika menurut persepsi siswa memiliki nilai rata-rata sebesar $73,86 \%$ yang termasuk ke dalam kategori sedang (2) konsep diri siswa memiliki nilai rata-rata sebesar $65,23 \%$ yang termasuk ke dalam kategori sedang (3) berdasarkan analisis data diketahui bahwa profil guru matematika berimplikasi dalam membangun konsep diri siswa. Hal ini terlihat dari harga $t$ hitung $=-0,836$ dengan nilai signifikansi $-0,836<0,05$ maka Ho ditolak dan Ha diterima, yang berarti ada implikasi profil guru dalam membangun konsep diri siswa.
\end{abstract}

Kata Kunci: Profil guru matematika, Kinerja Guru, Konsep Diri 
Vol III. No.2, Maret 2019, hlm. 107 - 116

Available online at www.jurnal.una.ac.id/indeks/jmp

Menurut Undang-undang No.20 (2003) tentang sistem pendidikan nasional, pendidikan adalah usaha sadar dan terencana untuk mewujudkan suasana belajar dan proses pembelajaran agar peserta didik secara efektif mengembangkan potensi dirinya untuk memiliki kekuatan spiritual keagamaan, pengendalian diri, kepribadian, kecerdasan, akhlak mulia, serta keterampilan yang diperlukan dirinya, masyarakat, bangsa, dan negara. Senada dengan pendapat Gunawan (2012) Pendidikan sebagai sebuah kegiatan proses aktivitas yang disengaja merupakan gejala masyarakat ketika sudah mulai disadari pentingnya upaya untuk membentuk, mengarahkan, dan mengatur manusia sebagaimana di cita - citakan masyarakat.

Namun ironinya, tujuan pendidikan di Indonesia masih menemukan berbagai kendala yang menghambat tercapainya tujuan pendidikan seperti yang diamanatkan dalam Undang-undang No.20 (2003) tentang sistem pendidikan nasional. Rendahnya mutu sumber daya manusia menjadi penyebab dari hal itu, kualitas pendidikan di Negara berkembang di Asia Pasific, Indonesia menempati peringkat 10 dari 14 negara berkembang. Salah satu faktor rendahnya kualitas pendidikan di Indonesia adalah karena lemahnya para guru dalam menggali potensi anak. Para pendidik sering kali memaksa kehendaknya tanpa pernah memperhatikan kebutuhan minat dan bakat yang dimiliki siswanya. Tetapi pendidikan di Indonesia semakin hari kualitasnya semakin rendah. Berdasarkan Survey United Nation Educational, Scientificand Cultural Organisation (UNESCO), terhadap kualitas pendidikan di negara-negara berkembang di Asia Pasific, Indonesia menempati peringkat10 dari 14 negara, sedangkan untuk kualitas para guru, kualitasnya berada pada level 14 dari 14 negara berkembang. Salah satu faktor rendahnya kualitas pendidikan di Indonesia adalah karena lemahnya para guru dalam menggali potensi anak (2010).

Pemerintah dan kalangan lembaga pendidikan harus lebih fokus kepada kualitas pendidikan yang saat ini dinilai masih jalan di tempat. Hal ini ditunjukkan dengan hasil Study PISA (Program for International StudentAssessment) tahun 2015 yang menunjukkan Indonesia baru bisa menduduki peringkat 69 dari 76 negara. Sementara itu dari hasil Study TIMSS (Trends in International Mathematics and Science Study) menunjukkan siswa Indonesia berada pada ranking 36 dari 49 negara dalam hal melakukan prosedur ilmiah. Kemampuan matematika siswa Indonesia masih memprihatinkan dengan peringkat ke-63 dari 70 negara, kalah jauh dibandingkan dengan Vietnam yang ada di peringkat ke12 dan Singapura di peringkat pertama. Survei Programme for International Student Assessment (PISA) yang dilakukan kepada siswa usia 15 tahun pada 2015, seharusnya bisa menjadi bahan evaluasi dalam mengejar ketertinggalan di bidang matematika, sebab matematika bukan hanya bidang ilmu tetapi Jung bahasa pengikat di antara ilmu-ilmu yang dipelajari, karena semua ilmu membutuhkan matematika, bahkan di bidang seni.

Salah satu komponen penting pendidikan adalah guru, berdasarkan Undang-undang No.14 (2005) tentang guru dan dosen dinyatakan bahwa guru adalah pendidik profesional dengan tugas 
Vol III. No.2, Maret 2019, hlm. 107 - 116

Available online at www.jurnal.una.ac.id/indeks/jmp

utama mendidik, mengajar, membimbing, mengarahkan, melatih, menilai dan mengevaluasi peserta didik. Definisi tersebut menuntut agar guru memiliki kualifikasi akademik, kompetensi dan sertifikat pendidik. Untuk menghasilkan kualifikasi akademik yang baik diperlukan sejumlah kompetensi yang meliputi kompetensi pedagogi, kepribadian, sosial, dan profesionalisme.Kompetensikompetensi tersebut diperlukan oleh seorang guru untuk dapat meraih sertifikat pendidik sebagai bukti keprofesionalannya. Kinerja guru mempunyai spesifikasi/kriteria tertentu, kinerja guru dapat dilihat dan diukur berdasarkan spesifikasi/kriteria kompetensi yang harus dimiliki oleh setiap guru. Berdasarkan Undang-undang No.16 (2007) tentang Standar Kualifikasi Akademik dan Kompetensi Guru, dijelaskan bahwa Standar Kompetensi Guru dikembangkan secara utuh dari 4 kompetensi utama, yaitu: kompetensi pedagogi, kepribadian, sosial, dan profesi. Keempat kompetensi tersebut terintegrasi dalam kinerja guru.

\section{Menurut Direktorat Tenaga} Kependidikan Nasional (2008) guru memiliki beberapa peran penting dalam dunia pendidikan, peran guru memang sangatlah banyak dan sarat dengan tanggung jawab. Peran guru yang dimaksud adalah berkaitan dengan peran guru dalam proses pembelajaran. Guru merupakan faktor penentu yang sangat dominan dalam pendidikan pada umumnya, karena profil seorang guru memegang peranan dalam proses pembelajaran, di mana proses pembelajaran merupakan inti dari proses pendidikan secara keseluruhan. Proses pembelajaran merupakan suatu proses yang mengandung serangkaian perbuatan guru dan siswa atas hubungan timbal balik yang berlangsung dalam situasi edukatif untuk mencapai tujuan tertentu, di mana dalam proses tersebut terkandung multi peran dari guru.

MenurutDirektorat Tenaga Kependidikan Nasional (2008) peranan guru meliputi banyak hal, yaitu guru dapat berperan sebagai pengajar, pemimpin kelas, pembimbing, pengatur lingkungan belajar, perencana pembelajaran, supervisor, motivator, dan sebagai evaluator. Peranan guru berkaitan dengan kompetensi guru, meliputi: Guru melakukan diagnosa terhadap perilaku awal siswa, guru sebagai pembuat RPP, guru sebagai pelaksana administrasi sekolah, guru sebagai komunikator, guru mampu mengembangkan keterampilan siswa, guru dapat mengembangkan potensi anak.

\begin{tabular}{ccc}
\multicolumn{2}{c}{ MenurutDirektorat } & Tenaga \\
Kependidikan & Nasional & (2008)
\end{tabular}
berdasarkan uraian tentang kompetensi dan peranan guru, tentu dapat diidentifikasi kinerja ideal seorang guru dalam melaksanakan peran dan tugasnya. Kinerja adalah performance atau unjuk kerja. Kinerja dapat pula diartikan prestasi kerja atau pelaksanaan kerja atau hasil unjuk kerja. Kinerja adalah performanc eisoutputderives kromprocesses, human otherwise, artinya kinerja adalah hasil dari suatu proses yang dilakukan manusia. Di sisi lain ukuran kinerja menurutDirektorat Tenaga KependidikanNasional (2008) dapat dilihat dari empat hal, yaitu: 1 . (Qualityof Works) kualitas hasil kerja 2. (Promptness) ketepatan waktu menyelesaikan pekerjaan 3. (Initiative) prakarsa dalam menyelesaikan pekerjaan 4. (Capability) kemampuan menyelesaikan 
Vol III. No.2, Maret 2019, hlm. 107 - 116

Available online at www.jurnal.una.ac.id/indeks/jmp

pekerjaan 5. (Comunication) kemampuan membina kerjasama dengan pihak lain. Standar kinerja perlu dirumuskan untuk dijadikan acuan dalam mengadakan penilaian, yaitu membandingkan apa yang dicapai dengan apa yang diharapkan. Standar kinerja dapat dijadikan patokan dalam mengadakan pertanggungjawaban terhadap apa yang telah dilaksanakan.

Menurut Ismail (2017) guru dalam proses pembelajaran di kelas dipandang dapat memainkan peran penting terutama dalam membantu peserta didik untuk membangun sikap positif dalam belajar, membangkitkan rasa ingin tahu, mendorong kemandirian dan ketepatan logika intelektual, serta menciptakan kondisi-kondisi untuk sukses dalam belajar. Menurut Haryanto (2016)pencapaian keberhasilan siswa yang diajar oleh guru yang memiliki kemampuan baik sangat berbeda dibandingkan dengan guru yang memiliki kemampuan rendah. Hasil penelitian yang dilakukan oleh Hammond di Carolina Utara menunjukkan bahwa guru yang memiliki kemampuan rendah dapat mempengaruhi rendahnya pencapaian keberhasilan belajar siswa dibandingkan dengan guru yang memiliki kemampuan baik. Proses pembelajaran yang dilakukan oleh guru dan siswa di dalam kelas salah satunya adalah proses pembelajaran matematika, sebelum kita membahas mengenai pembelajaran matematika, alangkah baiknya jika kita mengetahui terlebih dahulu mengenai matematika itu sendiri.

Menurut Badan Standar Nasional Pendidikan (2006) Matematika merupakan salah satu mata pelajaran yang perlu diberikan kepada semua peserta didik di sekolah, mulai dari tingkat sekolah dasar hingga tingkat sekolah menengah. Hal tersebut dapat dimengerti mengingat pentingnya peranan matematika dalam kehidupan, baik dalam menyelesaikan permasalahan yang berhubungan dengan perhitungan maupun dalam menunjang perkembangan cabang-cabang ilmu lain.Menurut Haryanto (2016) pembelajaran matematika sekolah merupakan suatu kegiatan manusia yang mencerminkan hasil karya matematikawan yakni mencari tahu mengapa dan bagaimana suatu teknik atau trik tertentu dapat bekerja, menemukan teknik baru, membenarkan pernyataan, dan lain sebagainya. Pembelajaran matematika juga harus mencerminkan bagaimana pengguna matematika menyelidiki masalah, menemukan variabel, memutuskan cara untuk mengukur dan menghubungkan variabel-variabel, melakukan perhitungan, membuat prediksi, dan memverifikasi kebenaran dari prediksi tersebut.

Namun pada kenyataannya, pelajaran matematika adalah momok menakutkan bagi sebagian siswa, adapun terkait nilai Ujian Nasional pada tahun 2016. Nilai Mata Pelajaran Matematika mengalami penurunan terbesar pada pelaksanaan Ujian Nasional (UN) SMP/sederajat pada 2016. Perubahannya dari 56, 28 pada 2015 menjadi 50, 24 di 2016. Yang terkoreksi paling besar adalah Matematika dengan penurunan sebesar 6 , 04 poin (Kemendikbud, 2016).Melalui pembelajaran matematika diharapkan guru mampu membangun konsep diri siswa, menurut Atikah (2016)Konsep diri merupakan penentu sikap individu dalam bertingkah laku, artinya apabila individu berpikir cenderung akan berhasil maka hal ini merupakan kekuatan atau dorongan 
Vol III. No.2, Maret 2019, hlm. 107 - 116

Available online at www.jurnal.una.ac.id/indeks/jmp

yang akan membuat individu menuju kesuksesan. Sebaliknya jika individu berpikir akan gagal, maka ini sama saja mempersiapkan kegagalan bagi dirinya. Kemandirian itulah proses belajar mengajar bagi orang dewasa lebihdi titik beratkan pada upaya menggali pengalaman dan mengadakanaktivitas berdasarkan pengalaman. Menurut (Syahril, 2017)konsep diri adalah bagaimana kita berpikir dan mengevaluasi diri kita seperti apa yang meliputi fisik, moral, personal, keluarga, dan dimensi situasi sosial. Konsep diri juga dipengaruhi oleh identitas diri. Konsep diri dikatakan sebagai pandangan sikap seseorangterhadap dirinya sendiri. Konsep diri seseorang erat hubungannyadengan gambaran dirinya, citra dirinya, penerimaan dan harga dirinya,penilaian dan karya dirinya.

Menurut Rianingsih (2013) konsep diri sebagaipandangan dan perasaan mengenai diri sendiri. Persepsi mengenai dirisendiri dapat bersifat psikis, sosial, dan fisik. Konsep diri dapatberkembang menjadi konsep diri positif dan negatif.Konsep diri adalah bahwa makhluk hidup yang bergantung pada orang lain, setelah menjadidewasa semakin sadar atas kemampuannya mengambil sikap sendiri.Kemudian dari pengalaman menunjukkan bahwa sudah mampumengembangkan dirinya. Bila keadaan ini terjadi pada seseorang, makadapat dikatakan bahwa orang itu telah memasuki alam dewasa. Jenjangkedewasaan telah terjadi perubahan kejiwaan, dari sikap yang tadinyatergantung pada orang lain menjadi sikap yang lebih mandiri.

Melalui observasi yang telah peneliti lakukan pada hari Senin 12
Februari 2018 di sekolah yang akan dijadikan tempat penelitian yaitu di SMPN 1 Lemahabang, serta melalui pengalaman pribadi peneliti yang pernah menjadi alumni di sekolah tersebut. Peneliti menemukan hal yang menarik dari keadaan sekolah tersebut, di mana sekolah tersebut telah banyak menyabet prestasiprestasi, baik itu prestasi di bidang akademik, seperti mata pelajaran Matematika maupun di bidang non akademik. Padahal ada guru yang dikatakan belum memiliki profil guru ideal, namun kelas yang diajar oleh guru yang memiliki profil guru ideal, hampir seluruh siswa di kelas tersebut telah memiliki konsep diri yang baik dan lebih unggul dibandingkan dengan kelas yang diajar oleh guru yang tidak memiliki profil guru ideal.

Dugaan peneliti konsep diri siswa yang terbentuk dipengaruhi oleh profil seorang guru. Salah satu contohnya konsep diri siswa yang negatif terhadap mata pelajaran matematika dikarenakan sang guru yang memiliki profil tidak menyenangkan pada saat mengajar di kelas tersebut. Argumen peneliti diperkuat dengan melakukan wawancara dengan guru, WAKASEK Kurikulum serta beberapa siswa, yang mana dari hasil wawancara tersebut dapat disimpulkan bahwa profil seorang guru mempengaruhi konsep diri siswa.

Berdasarkan pemaparan latar belakang di atas, terlihat bahwa guru di SMPN 1 Lemahabang memiliki profil guru ideal mampu membangun konsep diri positif pada siswa. Hal ini membuat penulis tertarik untuk melakukan analisis profil guru matematika dalam membangun konsep diri siswa. 
Vol III. No.2, Maret 2019, hlm. 107 - 116

Available online at www.jurnal.una.ac.id/indeks/jmp

\section{METODE}

Metode penelitian yang digunakan adalah metode penelitian kuantitatif dengan penelitian bersifat survei dan bersifat korelasional, desain penelitian yang digunakan oleh penelitian adalah One ShotCase Study. Menurut Sugiyono (2016)penelitianOne-ShotCase

Studyadalah penelitian yang dilakukan pada satu waktu terhadap satu kelompok.Paradigma dalam penelitian model ini dapat digambarkan sebagai berikut:

Keterangan :

$\mathrm{X}=$ Treatment yang diberikan (variabel independen) (guru matematika)

$0=$ Observasi variabel dependen (konsep diri siswa) $\mathrm{X} \rightarrow 0$

$\longrightarrow=$ Implikasi variabel $\mathrm{X}$ terhadap variabel Y

Menurut Nasehuddien\& Manfaat (2015) populasi dapat dibagi menjadi dua tingkatan (level) populasi, yaitu populasi target dan populasi terjangkau (target andexperimentallyaccesibelPopulation).

Berdasarkan pengertian di atas, maka populasi dalam penelitian ini: Populasi target pada penelitian ini adalah guru dan siswa SMPN 1 Lemahabang Kecamatan Lemahabang Kabupaten Cirebon Tahun Pelajaran 2018.Populasi terjangkau yang diambil yaitu 178 siswa, serta guru matematika.

Sampel dalam penelitian ini ditentukan dengan menggunakan teknik purposive sampling.adalah teknik penentuan sampel dengan pertimbangan tertentu agar data yang diperoleh nantinya bisa lebih representatif. Sampel yang digunakan dalam penelitian ini ialah sampel guru matematika yang berjumlah 5 orang dansampel siswa yang berjumlah 178 siswa.

Pada penelitian ini instrumen yang digunakan ialah observasi lembar PKG dan angket.Terdapat beberapa angketdigunakan diantaranya: 1) angket persepsi siswa terhadap profil guru matematika, bertujuan untuk mengetahui bagaimana profil guru matematika, 2) angket konsep diri siswa, bertujuan untuk memperoleh data konsep diri siswa.

Sebelum data dianalisa, maka dilakukan uji normalitas dan uji homogenitas. Setelah itu datadiuji menggunakan uji-t yang merupakan dasar dari pengambilan keputusan. Jika t hitung $>\mathrm{t}$ tabel, maka $\mathrm{H} 0$ ditolak. Namun jika $\mathrm{t}$ hitung $<\mathrm{t}$ tabel, maka H0 diterima.

\section{HASIL DAN PEMBAHASAN}

Pada penelitian ini, peneliti memperoleh data hasil rekapitulasi presentasi skor dari setiap dimensipenilaian kinerja guru berdasarkan penilaian kinerja guru (PKG) sebagai berikut:

Tabel 1

Rekapitulasi Hasil Penilaian Kinerja Guru

\begin{tabular}{clc}
\hline No & \multicolumn{1}{c}{ Dimensi } & Rata-rata Prosentase \\
\hline 1 & $\begin{array}{l}\text { Kompetensi } \\
\text { Pedagogi }\end{array}$ & $80,85 \%$ \\
\hline 2 & $\begin{array}{l}\text { Kompetensi } \\
\text { Kepribadian }\end{array}$ & $91,92 \%$ \\
\hline 3 & Kompetensi sosial & $88,10 \%$ \\
\hline 4 & $\begin{array}{l}\text { Kompetensi } \\
\text { Profesional }\end{array}$ & $80,85 \%$ \\
\hline
\end{tabular}


Vol III. No.2, Maret 2019, hlm. 107 - 116

Available online at www.jurnal.una.ac.id/indeks/jmp

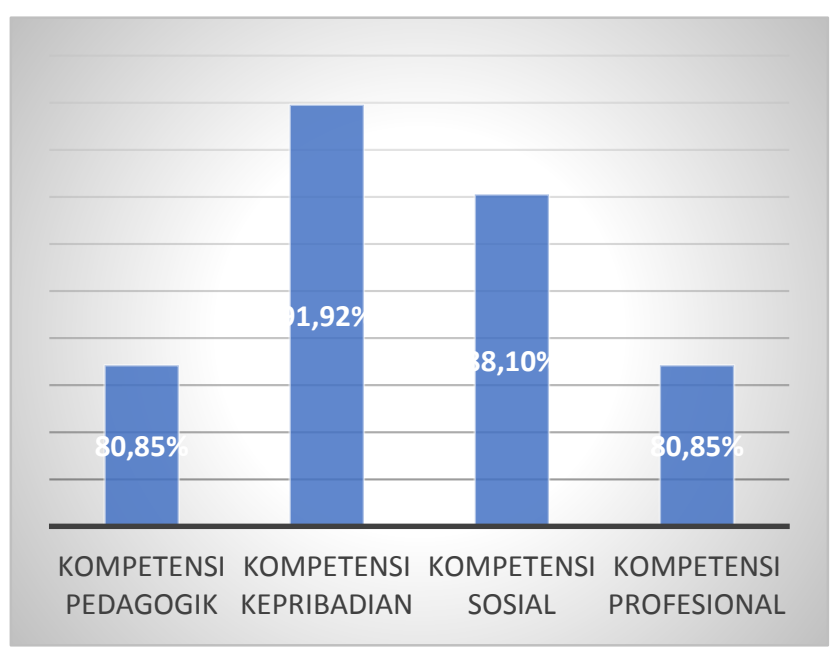

Gambar 1

Rekapitulasi Prosentase Skor dari Setiap

Dimensi Profil Guru Matematika berdasarkan PKG

Berdasarkan Tabel 1dan Gambar 1 rekapitulasi di atas, dapat di lihat bahwasanya rata-rata prosentase terbesar yang di dapat oleh guru matematika di Negeri 1 Lemahabang dari ke-4 kompetensi dasar dengan 14 indikator, berdasarkan penilaian kinerja guru adalah pada kompetensi kepribadian yaitu ratarata prosentase sebesar 91,92\% dengan nilai konversinya adalah sebesar 4 yang menjelaskan bahwa kompetensi kepribadian guru matematika di SMPN 1 Lemahabang sangat baik.

Hasil profil guru matematika selain didapat menggunakan lembar penilaian kinerja guru (PKG) yang di tentukan oleh dinas pendidikan kabupaten Cirebon, peneliti juga menggunakan angket persepsi siswa untuk lebih menguatkan hasil penelitian tentang profil guru matematika di SMPN 1 Lemahabang. Angket persepsi siswa tentang profil guru matematika di sebarkan kepada 178 siswa, sebelumnya kisi-kisi angket tersebut telah divalidasi oleh tim ahli yaitu Bapak Widodo Winarso, M. Pd. I danBapak Dr. Muhamad Ali Misri M. Si.

Hasil rekapitulasi presentasi skor dari setiap dimensi profil guru matematika pun diperkuat dengan hasil rekapitulasi presentasi skornya berdasarkan persepsi siswa, menurut Winarso (2016) persepsi masing-masing siswa tentang guru tidaklah selalu sama. Hal ini dikarenakan karakter, cara berfikir, latar belakang keluarga, dan pengalam-pengalaman masa siswa yang berbeda-beda, Hasil rekapitulasi presentasi skor dari setiap dimensi profil guru matematika berdasarkan persepsi siswa sebagai berikut:

Tabel 2

Rekapitulasi Prosentase Skor dari Setiap Dimensi Profil Guru Matematika

\begin{tabular}{|c|l|c|}
\hline No & \multicolumn{1}{|c|}{ Dimensi } & Rata-rata Prosentase \\
\hline 1 & $\begin{array}{l}\text { Kompetensi } \\
\text { Pedagogi }\end{array}$ & $75,84 \%$ \\
\hline 2 & $\begin{array}{l}\text { Kompetensi } \\
\text { Kepribadian }\end{array}$ & $76,20 \%$ \\
\hline 3 & Kompetensi sosial & $70,42 \%$ \\
\hline 4 & $\begin{array}{l}\text { Kompetensi } \\
\text { Profesional }\end{array}$ & $73,00 \%$ \\
\hline
\end{tabular}

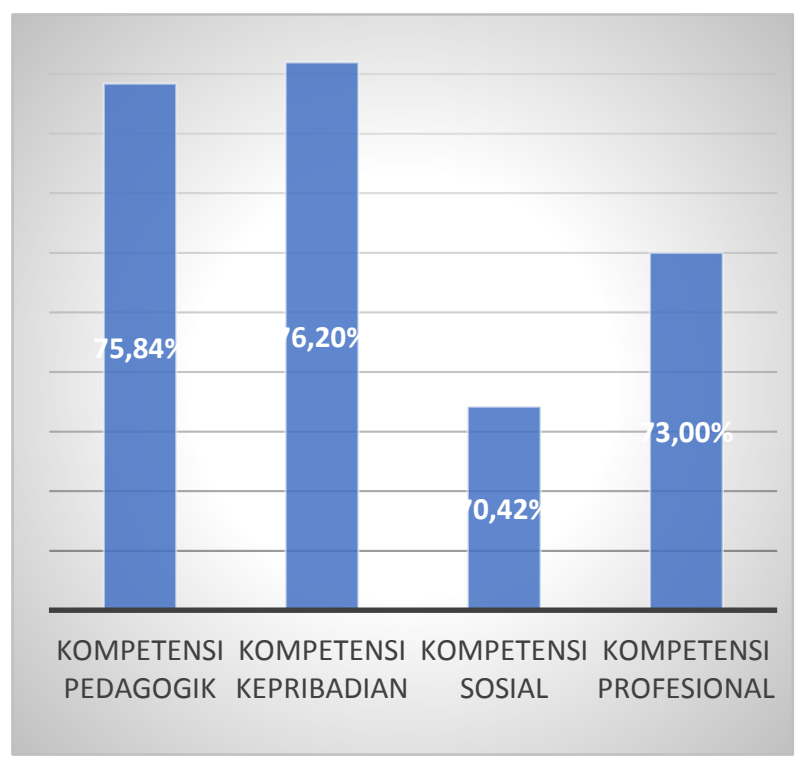


Vol III. No.2, Maret 2019, hlm. 107 - 116

Available online at www.jurnal.una.ac.id/indeks/jmp

\section{Gambar 2}

\section{Rekapitulasi Prosentase Skor dari Setiap \\ Dimensi Profil Guru Matematika berdasarkan Persepsi Siswa.}

Berdasarkan Tabel 2 dan Gambar 2 rekapitulasi di atas, dapat di lihat bahwasanya rata-rata prosentase terbesar yang di dapat oleh guru matematika di Negeri 1 Lemahabang dari ke-4 kompetensi dasar dengan 21 indikator, berdasarkan persepsi siswa terhadap guru matematika adalah pada kompetensi kepribadian yaitu rata-rata prosentase sebesar 76,00\% dengan nilai konversinya adalah sebesar 4 yang menjelaskan bahwa kompetensi kepribadian guru matematika di SMPN 1 Lemahabang sangat baik.

Adapun kontribusi profil guru matematika dalam membangun konsep diri siswa yang terbesar terletak pada dimensi kompetensi kepribadian guru. Rata-rata prosentasenya adalah sebesar 91,92\% dari penilaian kinerja guru (PKG) dan sebesar $76,20 \%$ dari hasil angket persepsi siswa. Guru yang menguasai kompetensi kepribadian akan sangat membantu upaya pengembangan karakter dan konsep diri siswa, dengan menampilkan diri sebagai sosok yang bisa digugu dan ditiru secara psikologis siswa cenderung merasa yakin dengan apa yang sedang diajarkan oleh guru. sejatinya kompetensi kepribadianlah yang amat berhubungan dengan pembentukan, pembangunan konsep diri siswa. Hal ini sejalan dengan isi kandungan Al- Quran surat Al- Mujadalah ayat 11 dan sangat terikat dengan kata di dalam surat An-Najm ayat 6, yaitu kompetensi kepribadian guru yang memiliki andil yang sangat besar terhadap keberhasilan pendidikan khususnya kegiatan pembelajaran dan pembentukan pribadi siswa. rekapitulasi presentasi skor dari setiap dimensikonsep diri siswa sebagai berikut:

Tabel 3

Rekapitulasi Prosentase Skor dari Setiap Dimensi Konsep Diri Siswa

\begin{tabular}{clc}
\hline No & \multicolumn{1}{c}{ Dimensi } & Rata-rata Prosentase \\
\hline 1 & Konsep diri positif & $71,00 \%$ \\
\hline 2 & Konsep diri negatif & $68,00 \%$ \\
\hline 3 & $\begin{array}{l}\text { Kemampuan } \\
\text { akademik }\end{array}$ & $58,94 \%$ \\
\hline 4 & $\begin{array}{l}\text { Kemampuan non } \\
\text { akademik }\end{array}$ & $63,00 \%$ \\
\hline
\end{tabular}

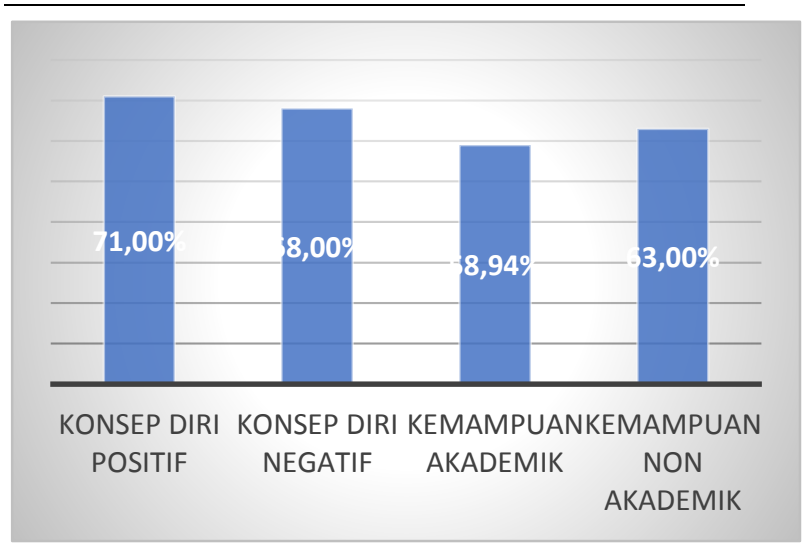

Gambar 3

Rekapitulasi Jumlah Skor dari Setiap Indikator Konsep Diri Siswa

Berdasarkan Tabel 3 dan Gambar 3 batang rekapitulasi di atas, dapat di lihat bahwasanya rata-rata prosentase terbesar yang di dapat oleh siswa di SMP Negeri 1 Lemahabang dari ke-4 dimensi konsep diri dengan 12 indikator, berdasarkan angket respon siswa adalah pada dimensi konsep diri positif yaitu rata-rata prosentase sebesar 71,00 \% dengan nilai konversinya adalah sebesar 3 yang menjelaskan bahwa konsep diri siswa di SMP Negeri 1 Lemahabang baik.

Hasil konsep diri siswa, dimensi konsep diri positiflah yang memiliki rata-rata 
Vol III. No.2, Maret 2019, hlm. 107 - 116

Available online at www.jurnal.una.ac.id/indeks/jmp

prosentase terbesar, yaitu sebesar $71,00 \%$. Hal ini dikarenakan konsep diri positif bersifat stabil dan bervariasi, serta sejalan dengan pendapat Hurlock bahwasanya konsep diri terbentuk dari lingkungan, pengalaman, dan pola asuh. Hal ini sejalan dengan hasil ke-4 kompetensi guru yang menunjukkan hasil kriteria baik, sehingga hasil konsep diri siswa yang dihasilkan pun menjadi unggul dalam konsep diri positifnya.

Masalah dalam penelitian ini ialah menguji ada tidaknya implikasi profil guru matematika dalam membangun konsep diri siswa. Berdasarkan analisis data diketahui bahwa profil gurumatematika berimplikasi dalam membangun konsep diri siswa. Hal ini terlihat dari harga $\mathrm{t}$ hitung $=-0,836$ dengan nilai signifikansi $-0,836<0,05$ maka Ho ditolak dan Ha diterima, yang berarti ada implikasi profil guru dalam membangun konsep diri siswa.

\section{SIMPULAN}

Berdasarkan hasil penelitian yang dilakukan, maka dapat diambil kesimpulan sebagai berikut:

\section{DAFTAR RUJUKKAN}

Ahmadi, A. (2005). Strategi Belajar Mengajar. Bandung: CV Pustaka Setia.

Atikah, S. A. (2016). Pengaruh Persepsi Siswa tentang Kompetensi Guru, Konsep Diri, dan Minat Belajar terhadap Hasil Belajar Ekonomi Siswa Kelas XI IPS Semester Genap SMA Negeri 1 Way Tenong Lampung Tahun Ajaran 2015/2016
1. Profil guru matematika menurut hasil penilaian kinerja guru memiliki nilai rata-rata sebesar $85,43 \%$ yang termasuk ke dalam kategori baik. Diperkuat dengan profil guru matematika menurut persepsi siswa memiliki nilai rata-rata sebesar $73,86 \%$ yang termasuk ke dalam kategori sedang.

2. Konsep diri siswa memiliki nilai ratarata sebesar $65,23 \%$ yang termasuk ke dalam kategori sedang.

Berdasarkan analisis data diketahui bahwa profil guru matematika berimplikasi dalam membangun konsep diri siswa. Hal ini terlihat dari harga $\mathrm{t}$ hitung $=-0,836$ dengan nilai signifikansi $-0,836<0,05$ maka Ho ditolak dan Ha diterima, yang berarti ada implikasi profil guru dalam membangun konsep diri siswa.

Gunawan, H. (2012). Pendidikan Karakter. Bandung: Alfabeta.

Haryanto, J. M. (2016). Pengembangan Instrumen dan Penilaian Kinerja Guru Matematika SMP di Kabupaten Ende. Jurnal Evaluasi Pedidikan, 134-145.

Ismail. (2017). Kinerja dan Kompetensi Guru dalam Pembelajaran. Jurnal Ilmu Tarbiyah dan Keguruan , 4463. 
Vol III. No.2, Maret 2019, hlm. 107 - 116

Available online at www.jurnal.una.ac.id/indeks/jmp

Kemendikbud. (2016). nilai UN Matematika . Jakarta: Republika.

Kustandi, C., \& Sutjipto, B. (2013). Media Pembelajaran. Bogor: Ghalia Indonesia.

Mahendra, Y. I. (2005). Undang-undang No.14 Guru dan Dosen.

Mattalatta, A. (2003). UU No.20 Tentang Sistem Pendidikan Nasional. Indonesia.

Najichun, M., \& Winarso, W. (2016). Hubungan Persepsi Siswa tentang Guru Matematika dengan Hasil Belajar Matematika Siswa. Jurnal Psikologi Undip , 15(2), 139-146.

Nasehuddien, B. M. (2015). Dasar-dasar Metodologi Penelitian. Cirebon: Eduvision.

Nurohimah, S., Kuriniawan, E. S., \& Ashari. (2012). Pemanfaatan Kartun Fisika Sebagai Media Pembelajaran Untuk Meningkatkan Motivasi Belajar Pada Siswa Kelas VII Mts N Purworejo. Jurnal Radiasi .

Persada, A. R. (2017). Peningkatan Hasil Belajar Matematika Melalui Pengembangan Bahan Ajar Berbasis Website. Eduma , 6 (1), 65.

Rianngsih, E. (2013). Hubungan Konsep Diri dengan Prestasi Belajar Matematika Siswa Kelas VIII SMP Negeri 2 Salatiga . Doctoral dissertation .

Riyana, C., \& Susilana, R. (2009). Media Pembelajaran. Bandung: $\mathrm{CV}$ Wacana Prima.
Sadiman, A. S. (2012). Media Pendidikan. Depok: PT Rajagrafindo.

Setyono, E. Y. (2014). Pengaruh Penggunaan Media Pembelajaran Kartun Fisika Terhadap Motivasi Belajar Mahasiswa Pada Mata Kuliah Fisika Terapan. Jurnal Sosoal dan Humaniora , 89.

Siana, G. (2010, 09 16). Mutu pendidikan Indonesia. Retrieved from http:/mentasmaning.gurusiana.id

Sudibyo, B. (2007). Undang-undang No.16 tentang Standar Kualifikasi Akademik dan Kompetensi Guru.

Sudjana, N., \& Rivai, A. (2013). Media Pengajaran. Bandung: Sinar Baru Algesindo.

Sugiyono. (2016). Metode Penelitian Pendidikan (Pendekatan Kuantitatif, Kualitatif, dan $R \& D)$. Bandung: Alfabeta.

Syahril, S. H. (2017). Analisis Prilaku Konsmen Terhadap Keputusan Pembelian Ponsel. Jurnal Online Mahasiswa (JOM) Bidang Manajemen, 1.

Uno, H. B. (2013). Teori Motivasi dan Pengukurannya. Jakarta: PT Bumi Aksara.

Yasunari, S. B. (2010). Konsep Pendidikan Ki Hajar Dewantara dan Tantangan-Tantangan Implementasinya di Indonesia Dewasa ini. Bandung: Universitas Parahiyangan 